\title{
Using "Ag in the Classroom" curricula: Teachers' awareness, attitudes and perceptions of agricultural literacy ${ }^{1}$
}

\author{
Cynthia L. Malecki, Glenn D. Israel, and Elena Toro²
}

\section{Introduction}

Florida's residents are more dependent than ever on agriculture, but for many the relationship is invisible. This is because it is masked by the proliferation of widely available food products on store shelves and numerous intermediaries in the food processing, distribution and marketing system. The mission of agricultural education today is to create an awareness of this progression as well as the need for the agricultural industry. Additionally, agricultural education should create awareness about how newly developed technologies have become an integral part of the world's production of food and fiber.

Agricultural education creates agricultural literacy in youth in grades K-12. Agricultural literacy is defined as an understanding of the food and fiber system, which includes its history and its current economic, social, and environmental significance to Americans. This definition encompasses some knowledge of food and fiber production, processing, and domestic and international marketing. Agriculturally literate people should have the practical knowledge needed to care for their outdoor environments, which includes lawns, gardens, recreational areas, and parks (National Research Council, 1988 p. 8-9).

Increasing agricultural literacy is important because it can help citizens make informed choices as voters to support or oppose public policies on agriculture-related issues, such as genetically-modified organisms in food production, food safety, and on food security, environmental quality, and land use. Developing agricultural literacy, however, depends on the mainstream educational system, particularly on the awareness and attitudes of teachers as they make decisions about what and how to teach the future citizenry of the U.S.

The majority of American children know little about agriculture upon entering school and show little improvement in agricultural literacy by the time they graduate (National Research Council, 1988).

1. This document is AEC 370, a publication of the Agricultural Education and Communication Department, Florida Cooperative Extension Service, Institute of Agricultural and Food Sciences, University of Florida. Publication date January, 2004. Visit the EDIS website at http://edis.ifas.ufl.edu.

2. Cynthia L. Malecki, former Graduate Assistant; Glenn D. Israel, Professor; and Elena Toro, Graduate Assistant, Department of Agricultural Education and Communication, Institute of Food and Agricultural Sciences, University of Florida, Gainesville, 32611. This fact sheet is based on Dr. Malecki's dissertation, "Adoption of Agriscience Curricula: Teachers' Awareness, Attitudes and Perceptions of Agricultural Literacy." Dr. Malecki completed her Ph.D. in August, 2003, and, sadly, succumbed to cancer in September, 2003. The authors wish to thank Larry Arrington and Tracy Irani for reviewing an earlier draft.

The Institute of Food and Agricultural Sciences (IFAS) is an Equal Employment Opportunity - Affirmative Action Employer authorized to provide research, educational information and other services only to individuals and institutions that function without regard to race, creed, color, religion, age, disability, sex, sexual orientation, marital status, national origin, political opinions or affiliations. For information on obtaining other extension publications, contact your county Cooperative Extension Service office. Florida Cooperative Extension Service / Institute of Food and Agricultural Sciences / University of Florida / Larry R. Arrington, Interim Dean 
Teachers of K-12 students have the potential to educate and bring about desired changes by incorporating agriculture-related topics.

Agricultural literacy can be best achieved through curriculum infusion in grades K-12. Curriculum infusion is the purposeful integration of agricultural topics into the mandated curriculum in urban and suburban as well as in rural schools. These topics are included as natural interdisciplinary linkages. Teachers connect the natural sciences, mathematics, social and behavioral sciences to help students understand the world in which they live (Balschweid and Thompson, 2000).

\section{$\mathrm{Ag}$ in the Classroom}

In order to provide the essential tools for educators to achieve agricultural literacy, national and state-specific curriculum materials have been developed by the Agriculture in the Classroom Program (AITC). All the states, U.S. territories, and the District of Columbia have Agriculture in the Classroom Programs (USDA, 2001). USDA curriculum resources for elementary, secondary, and collegiate levels are found both in the literature and in numerous websites.

The recognition of the need for agricultural education has drawn attention to teacher education. Educators play a key role because they make decisions about the content and curricula taught in their classrooms. Agricultural education workshops can provide teachers with the necessary knowledge base to deliver agriculture-related curricula in their classrooms. For example, teacher workshops to promote these types of programs are offered all year in Florida. During the summer, Florida Agriculture in the Classroom, Inc. (FAITC), a non-profit organization working to develop agricultural curricula and materials, sponsors an intensive three-day workshop. Despite extensive recruitment efforts by FAITC staff, the number of participants in FAITC workshops between 1999 and 2002 was below desired levels. Furthermore, a disproportionate number of participants teach in rural areas. Consequently, it is not yet evident whether students from urban and suburban areas of the state are equally interested in agriculture.

\section{A Closer Look at Teachers}

A study was conducted to determine how attitudes, perceptions, and prior knowledge affect teachers' participation in agricultural education workshops. To better understand reasons behind teachers' decision-making, Ajzen's (1991) theory of planned behavior was applied to the case of agricultural education. This theory emphasizes that a person's intention in attending a workshop is the key factor for determining that attendance. Likewise, intention is determined by a teachers' attitudes, knowledge and perceptions.

A mail survey was sent to a sample of teachers in Florida's public elementary and secondary schools. The study compared teachers who had attended one or more FAITC workshops with teachers who had not done so. Of the 230 usable responses, 97 were from teachers who had been participants in one or more FAITC workshops, and 133 were from teachers who had not participated in a workshop.

Findings:

- Previous FAITC workshop participants have strongly held attitudes motivating their choices of future workshops. Those who have not yet participated in an FAITC workshop, on the other hand, appear to be affected more by the opinions and values--as well as the authority--of others such as such as administrators, colleagues, and students' parents.

- Both groups were strongly influenced by the prospective payment of a stipend to attend a workshop. Teachers expect to be compensated for costs associated with attending workshops.

- Teachers who were more favorable toward agricultural education had rural influences or backgrounds, or were teachers at elementary schools. By contrast, more teachers in urban areas and high school teachers (grades 9-12) held negative perceptions of agricultural education and had little confidence in teaching it.

- There is weak interest and unfavorable perceptions are held by many teachers about improving agricultural awareness and literacy. 
On the other hand, they have positive perceptions about biological, environmental and science topics. Using agricultural examples, however, can increase the acquisition of basic science and math process skills (Mabie and Baker, 1996). Thus, the skills learned through infusion of agricultural education can support the development of those measured by mandated testing, while at the same time benefiting students.

\section{Implications for FAITC}

Based on the findings above, Florida Ag in the Classroom program leaders should consider implementing the following recommendations:

- Raise agricultural literacy and awareness by challenging agricultural educators at local schools and universities to work more with teachers and future educators.

- Because nonparticipating teachers are strongly influenced by their administrators, including principals and curriculum coordinators, administrators can be recruited to help promote agricultural education. FAITC could send a message to school administrators that will 1) emphasize the benefits of ag education for the administrator's students, 2) stress the need for administrator to empower teachers to make the decision to attend FAITC workshops, 3) stress the need for administrator to support the teachers' decisions to attend workshops by approving their requests.

- Involve teachers who have successful Ag in the Classroom programs in promotional activities and messages. They have credibility with their peers and can attract other teachers who want to emulate these successful programs.

- Use direct mail flyers and emphasize opportunities to gain new ideas applicable to teaching mandated curricula effectively to recruit teachers to workshops.

- Illustrate in promotional communications and training workshops that agricultural education is indeed biological and environmental science. This message should emphasize the use of advanced technological science in modern agriculture; that is, principles of the physical, chemical and biological sciences are used in the food and fiber system.

Additional recommendations can be made to increase teachers preparation for agricultural education. These might include:

- Establish greater linkages between the colleges of agriculture and education for training prospective teachers.

- Insert FAITC workshops into college classrooms to prepare future educators for incorporating agricultural literacy in their own classrooms.

- Encourage experienced teachers to model curricular integration and demonstrate exemplary teaching.

- Incorporate agriculture -related Internet resources and web links into pre-intern teachers' computer classes.

- Develop a linkage with undergraduate science courses and career awareness counselors to enhance a focus on the full spectrum of career potential related to agricultural sciences.

\section{Closing Comments}

If agricultural literacy is to be increased, greater efforts must be made to recruit urban and suburban teachers because they work with the majority of Florida's students. Adopting the above recommendations can help recruit these teachers to FAITC workshops and, in turn, increase outreach to students. In addition, more teachers, especially those in biological and environmental sciences, need to be trained during college in order to build a cadre of agriculturally literate teachers in Florida's schools.

\section{References}

Ajzen, I. (1991). The theory of planned behavior. Organizational Behavior and Human Decision Processes, 50:179-211. 
Balschweid, M.A., Thompson, G.W., Cole, R.L. (2000). Agriculture and science integration: A pre-service prescription for contextual learning. Journal of Agricultural Education, 41(2):36-45.

Mabie, R., Baker, M. (1996). A comparison of experiential instructional strategies upon the science process skills of urban elementary students. Journal of Agricultural Education, 37(2):1-7.

National Research Council, Committee on Science Education Standards and Assessment (1995). Understanding Agriculture: New Directions for Education. Washington, DC: National Academy Press.

United States Department of Agriculture [USDA] (2001). Secondary Agriculture Education Challenge Grants. Washington, DC: USDA, Cooperative State Research, Education, and Extension Service, Science and Education Resources Development, Higher Education Programs. http://faeis.usda.gov/documents/grants/secondary/ second01.html (Accessed April 20, 2003).

United States General Services Administration (2003). FirstGov. Washington, D.C.:U.S. General Administration Services Administration, Office of Citizen Services and Communications.

http://www.firstgov.gov/fgsearch/index.jsp (Accessed February 26, 2003). 